\title{
Markets on the edge: Beach kiosk TripAdvisor consumer online reviews as dataset to compare Australian and Brazilian beachfront collective representations
}

\author{
Marina Sartore' \\ Brian Coffey ${ }^{2}$
}

\section{Abstract}

Consumer online reviews are written by amateurs, are published very fast, and are freely accessible by anyone having internet access, bringing analytical challenges to the Social Sciences. In this exploratory paper, we compare Australian and Brazilian beach kiosk TripAdvisor Written Reviews (TWRs) and argue that they are a useful source to perceive differences in beachfront collective representations. We also argue that to better understand the socio-logics of beachfront collective representations, the content analysis of TWRs alone can be limited; therefore, we draw on other qualitative methods, such as document analysis and field observation. By combining such methods, we conclude that Australian and Brazilian beachfront collective representations differ in categories of time and space. Understanding beachfront collective representations of different countries can bring consistent knowledge to help politicians tackle current coastal challenges, especially the balance between commercial development and natural conservation of the beachfront.

Keywords: Economic Sociology, Seaside; Digital Media; Consumption, Big data.

\section{Introduction}

Beachfronts are intriguing places. Once only wild and exotic, beaches have incorporated diverse uses over the years, becoming places for leisure,

\footnotetext{
I Associate Professor of Sociology at the Federal University of Sergipe. Researcher at the Postgraduate Program of Sociology and at the Postgraduate Program of Environment and Development. Contact author: marinass@ufs.br

2 Professor at the Royal Melbourne Institute of Technology. Researcher at the Centre for Urban Research.
}

\section{$((c))$ EY}

Direito autoral e licença de uso: Este artigo está licenciado sob uma Licença Creative Commons. Com essa licença você pode compartilhar, adaptar, para qualquer fim, desde que atribua a autoria da obra, forneça um link para a licença, e indicar se foram feitas alterações. 
curing diseases, transgressing laws (CORBIN, [1988] 1990; URBAIN, [1994] 2002; AZEVEDO, 2008), and commerce (SPEARRITT, 2003; SARTORE, 2017). In Brazil, we find beach kiosks among the many typical commercial façades of the beach. For instance, in the city of Aracaju, located in the Northeast of Brazil, there are around 50 beach kiosks on a $16 \mathrm{~km}$ stretch of coast, where people pay to have fun (paying for meals and drinks) on a free space (the beach). In doing so, it is common for these people to get on their smartphones and write reviews, such as the following one, posted on TripAdvisor ${ }^{3}$.

Great Choice! Lots of food, beer options. Good lunch and snacks. The Waitress [name] provides a very good quality service, very attentive!! Price is fair, clean toilets, shower available, playground for children (B2E70 - translated from Portuguese by the authors).

On the other side of the world, in Melbourne (Port Phillip Bay), Australia, there are two beach kiosks where people, in a similar fashion, also pay to have fun (paying for meals and drinks) on a free space (the beach). In a similar fashion, these people also get on their smartphones and write reviews, such as the following one, posted on TripAdvisor.

Nothing beats a good ol' Aussie brekkie [breakfast] on the beach [...] fantastic eggs Benedict, the strongest espressos, sides of bacon, feta, oh the marinated portobello mushrooms, how do they do that? I love to sit outside on the big old picnic table made out of heavy timber beams and watch beach goers, kiddies, puppies and the rolling waves right at my feet. Nothing beats [the kiosk] for location, an early morning swim, a relaxing beach walk and the best brekkie this side of Port Phillip Bay) (B3EI0).

These are consumer online reviews $\left(\mathrm{CORs}^{4}\right)$ about experiences at beachfront kiosks. Different from expert reviews, which are published by specialized newspapers or travel guides, CORs are written by amateurs ${ }^{5}$, are published very fast, and are freely accessible by anyone having internet

3 TripAdvisor was launched in 2000 and is now available in 49 countries. It has 490 million average monthly unique visitors and an annual revenue of $\$ 1.62$ billion (IR.TRIPADVISOR, 2019).

4 Amazon (ww.amazon.com) pioneered the Online Consumer Review platforms (BEAUVISAGE et al., 2013). Nowadays, there are many others, such as TripAdvisor (www.tripadvisor.com); Yelp (www.yelp.com); Zomato (www.zomato.com).

5 The use of the word "amateur" means that the reviewers don't necessarily have the skills, nor the credentials, that would turn them into professional reviewers, such as the reviewers from the Michelin 3 stars rating system. 
access. CORs tend to increase along with the growing number of listed restaurants on TripAdvisor, that jumped from 2.4 million to 4.9 million in the last four years (STATISTA, 2019).

As the number of people that use online platforms grows, using them to share products, services and information, the bigger the impact on people's daily lives (ORLIKOWSKI; SCOTT, 2014; CARDON, 2015), creating a new source of information that challenges the expert trust system (JEACLE; CARTER, 2011), and, by and large, changing the touristic imagery of destinations (TAMAJÓN; VALIENTE, 2015). On that note, this paper will focus on TripAdvisor written reviews (from now on, TWRs), more specifically, reviews about experiences in beach kiosks, seen as beachfront commercial experiences intermediated by money, where people pay for meals and drinks with a view of the beach. Within this scope, beach kiosks can be fancy restaurants or humble shacks, and can be found in many places around the world, as shown by the CNN travel (GERRIE, 2013) ${ }^{6}$ ranking of the world's 50 best beach bars.

In this exploratory paper, we argue that TWRs are a useful source to perceive and compare international collective representations, or narratives that emerge from social interactions, such as Brazilian and Australian beachfront collective representations. By collective representations we address, more specifically, narratives that overcome social relations and become stable in the form of beliefs, laws and moral codes that constrain social behaviour (DURKHEIM, 1898). However, we argue that to better understand the socio-logics of (beachfront) collective representations, TWRs alone are limited, and need to be combined with other qualitative methods.

This argument is developed in the paper in four sections: First, we present our understanding of the association between TWRs and collective representations. Second, we present the content analysis framework used on TWRs of two beach kiosks from Brazil and two beach kiosks from Australia; the resulting data is presented as empirical evidence to support our argument. Third, we present the following results: (1) TWRs can be used as a source of data to compare collective representations internationally.

6 Information available at: https://edition.cnn.com/travel/article/worlds-best-beach-bars/index.html. 
The same eight categories emerged from the analysis of the TWRs of the selected Australian and Brazilian beach kiosks: Food+Beverage; Infrastructure; Service; Definition; Price; Location; Beach and Scenario; Experience Detail. This means that patterns are created by TripAdvisor, which enables comparative research/analysis. (2) Although the same categories emerged from the analysed TWRs, their content and frequency vary, showing that these countries have different collective representations about beach kiosks and, more generally, beachfronts. To highlight these differences, we present a more detailed account of the results of the content analysis categorized as Food+Beverage, Beach and Scenario, and Infrastructure, demonstrating particularities related to each country's beachfront collective representations. We also argue that we can better explain how these particularities are framed only by combining other methods of analysis, such as field observation and document analysis. Fourth, we conclude that the dynamics of the Australian and Brazilian beachfront collective representations vary according to classifications of time and space and indicates a strong relation to the drinking culture and to the empowerment of the local community. Further research is needed to better understand how these relations develop in particular contexts.

\section{TripAdvisor written reviews as collective representations}

At a first glance, TWRs look like a myriad of independent and individual evaluations. Yet, they express a general, tacit and collective narrative about what is expected to be found, and how people are expected to behave, for example, in a beach kiosk. These narratives are collective representations (DURKHEIM, 1898) that are produced from social interactions that happen at the beach kiosk and are objectified into online reviews expressing external, general, coercive beliefs, laws and moral codes. Collective representations can be found not only in content (what one writes), but also in the shape (how one writes).

Beachfront collective representations can vary. For example, Peyvel's (2008) field observations identified different and opposite collective behaviours between two near beaches in Vietnam: the 
"occidental beach", frequented predominantly by Western tourists, and the "Vietnamese beach", frequented predominantly by Vietnamese people. Peyvel argued that: while "Westerns" value the beach mostly for its beauty, the Vietnamese value its functionality; while Westerns like to get a tan, the Vietnamese tend to stay under the shade (having pale skin is a sign of good health in the local culture); while in the "occidental beach" there are garbage bins everywhere, and most Westerns make use of them, the Vietnamese tend to leave the remains of eaten crustaceans all over the floor. Finally, while Westerns usually shop in boutique stores that have fixed prices and are located near the beach, the Vietnamese bargain with independent vendors that make rounds on the beach offering different products.

When differences like those described above appear in TWRs, more than simply expressing different descriptions of different collective behaviors, they express judgments of value. To paraphrase Durkheim (1911), every time we evaluate, we mobilize a whole external structure of classifications that orient our judgment. In this perspective, TWRs are ideals and beliefs that concretely operate as the values of a society. Durkheim (1911) gives the example of marriage as an ideal, or a judgment of value, shared by a homogeneous society; once divorces and adulteries start happening, they are treated as menaces by those sharing the marriage ideal. Following this perspective, once TripAdvisor reviewers evaluate, they face a whole external structure of beachfront kiosk classifications that is seen as ideal for the society they belong to. If they share and experience the same set of classifications, the review will certainly be positive. If they don't, the non-orchestrated experience will result in social sanctions in the form of a negative review. However, it's important to highlight that TripAdvisor has a high consumer experience rate of 3.8 out of 5.0 stars, showing that TripAdvisor portrays "consumer experiences of happiness" (CARDON, 2014), thus, mostly reflecting the ideal associated to beachfront collective representations. 


\section{Brazilian and Australian beach kiosk reviews: context and methodological framework}

The dataset analysed in this paper comes from 200 TWRs about the two top-ranked beach kiosks (B1 and B2 ${ }^{7}$ ) located in Aracaju's Expansion Zone, in the state of Sergipe, Brazil, and another 200 TWRs about two beach kiosks located in Port Phillip Bay, in the Australian state of Victoria (B3 and $\mathrm{B} 4^{8}$ ). The 400 beach kiosk TWRs are presented as judgements of people's eating and drinking experiences at the beachfront. Also, the portrayed beach kiosks (B1, B2, B3 and B4) are among the selected case studies of an international research project that compared beach commercial development in Australia and Brazil .

Researchers face analytical challenges in using data produced by online applications (BOYD; CRAWFORD, 2012; KITCHIN, 2014; GOLD; KLEIN, 2016). Cousin et al. (2014) argue that TripAdvisor can be used by social scientists to understand patterns of social collective travel behaviour, where available data, such as age, gender and travellers' location can be used to understand which region gets more comments and what kind of travellers they receive. For this article, the challenge of using TWRs as a source of data is the lack of access to accurate information about the reviewers' general profile.

To be able to analyse the beachfront collective representations presented in the TWRs, we need to know from which social group they derive. Thus, we divided the 400 TWRs into Group one, with the 200 reviewers of Brazilian beach kiosks, and Group two, with the 200 reviewers of Australian beach kiosks.

7100 TWRs about BI, from January 2015 to February 2017; and 100 TWRs about B2, from August 2012 to February 2017.

8100 TWRs about B3, from November 2014 to October 2018; and 100 about B4, from February 2015 to November 2018.

9 The international project "Free and unrestricted beach access and the relation between nature and forms of commerce on the beach: a comparative study between Australia and Brazil" was developed by the authors of this paper from September 2018 to August 2019. The project comparative analysis was between countries. However, in this paper, every time we mention "Brazilian beach kiosks" we are referring to the two analysed beach kiosks in Aracaju's Expansion Zone; every time we mention "Australian beach kiosks" we are referring to the two analysed beach kiosks at the Port Phillip Bay area. 
Females and Males are relatively well distributed in both groups (37\% females and $43.5 \%$ males in Group one; $33.5 \%$ females and $28 \%$ males in Group two). The TripCollective (TRIPADVISOR. 2019b) ${ }^{10}$ highest levels (from 04 to 06 ) are 63\% for Group one and 66.5\% for Group two. Therefore, the TWRs of our sample are well distributed by gender, and the majority are experienced contributors to the online platform.

Group one is formed mainly by Brazilian domestic tourists and locals ${ }^{11}$ $(71 \%)$. Group two is formed mainly by locals ${ }^{12}(52 \%)$; and, if we add the reviewers from other Australian states, the percentage grows to $66 \%{ }^{13}$. Overall, the TWRs about the Brazilian beach kiosks are written mainly by Brazilians, and the TWRs about the Australian beach kiosks are written mainly by Australians. As a result, we can affirm that the beachfront collective representations are produced, by and large, by people from the same nationality.

Both countries have high rates of households having internet access: $70.5 \%$ in Brazil (AGÊNCIA IBGE NOTÍCIAS, 2018) and 86\% in Australia (ABS, 2018). In both countries there is also a direct association between higher income and higher probability of internet access. In Brazil, $92 \%$ of those earning more than 10 times the minimum wage have internet access, against $54 \%$ of those earning up to 01 minimum wage ${ }^{14}$ (SANTOS, 2016). In Australia, 96\% of those in the highest income quintile have internet access, against $67,4 \%$ in the lowest quintile ${ }^{15}$ (THOMAS; WILSON; PARK, 2018). This data associating income and internet access points out the high probability that the TWRs of our sample are written,

10 TripCollective Level is a "contributor program that recognizes each time [someone] add to TripAdvisor". There are 06 levels, from 0 to 06 . The more someone contributes, the more points and higher the level earned. Information available at: https://www.tripadvisor.com/vpages/tripcollective_faqs.html.

II Those from the state of Sergipe, Brazil.

12 Those from the state of Victoria, Australia.

13 These percentages are likely to be bigger. The percentage of people that don't mention their home country is relatively high (29\% for the Brazilian beach kiosk TWRs and $22 \%$ for the Australian beach kiosk TWRs). However, by reading the TWRs, the language and local expressions used in the review indicate that many of those not mentioning their origins might be Brazilians (in TWRs from Brazilian kiosks) and Australians (in TWRs from Australian kiosks).

14 Data from 2015.

15 Data from 2018. 
in a higher percentage, by people with higher incomes, also considering the costs involved in frequenting a beach kiosk.

Another important characteristic of online reviewers is their amateurism. Soon after TripAdvisor was created, it started to allow independent persons to write reviews. Shortly after, the application started to receive several crowdsourced reviews (KINSTLER, 2018). As a result, TripAdvisor became an online application where amateurs could review, as well as check upon other amateurs' reviews, creating a whole new structure opposing that of expert reviews built by the creators of the Michelin Guide in France ${ }^{16}$. To summarise, the TWRs of our sample produce beachfront collective representations coming mainly from "experienced" local amateur male and female contributors, probably coming from higher income levels of Brazilian and Australian society.

This dataset (SARTORE, 2019) ${ }^{17}$ analysis follows the methodological procedures for content analysis proposed by Moraes (2003). First, we listed the 400 TWRs on an excel spreadsheet and gave each of them a code. For example: the first review of beach kiosk 01 was coded as B1E1 (B1=Beach Kiosk 01; E1=Evaluation 01]; the second review of beach kiosk 01 was coded as B1E2; therefore, the first review of beach kiosk 02 was coded as B2E1, and so on. Then, we divided each of the phrases and clauses that expressed an independent idea into units of meaning $(\mathbf{U})$. The example below shows the review coded as B1E5 (fifth review of the beach kiosk 01) with the six created units of meaning $(\mathbf{U})$.

Great location. [B I E5U1] Ok food. Average coffee. [B I E5 U2] Right on the beach with both inside and outside tables. [B I E5U3] Counter ordering. Quick service. [B I E5 U4] Eggs on toast ok but coffee bland. Fruit toast excellent. [B I E5U5] Nice place on a nice day, but don't go just for the food. [B I E5U6].

The next step was the process of categorization, where categories were created to cluster together all units of meaning that presented a similar judgement of the beach kiosk experience. The same eight categories emerged

16 Karpik (2000) is a good source to learn more on how the "Michelin expert review" was created and legitimated.

17 The dataset from the Australian case is available at: https://www.researchgate.net/publication/332304794_ Australian_Beach_Bar_Trip_Advisor_Excel. upon request. The dataset from the Brazilian case is available by email upon request. 
from both Brazilian and Australian TWR analysis: (1) Definition ("the bar is...”); (2) Infrastructure ("the bar infrastructure has...”); (3) Food and Beverage ("food and beverages are..."); (4) Service ("the service is..."); (5) Location ("the location is..."); (6) Beach and Scenario ("the views are..."); (7) Price ("the prices are..."); and (8) Experience Detail (details and additional subjective information written to start or finish a review). Going back to the same example given above, the 6 units of meaning from Review B1E5 are allocated to seven different categories, as underlined below:

Great location. [BIE5UI] Location Ok food. Average coffee. [B IE5U2] Food+Beverages Right on the beach / with both inside and outside tables. [B I E5U3] Location/Infrastructure ${ }^{18}$ Counter ordering. Quick service. [B I E5 U4] Service Eggs on toast ok but coffee bland. Fruit toast excellent. [B I E5U5] Food+Beverages $\underline{19}$ Nice place on a nice day, but don't go just for the food. [B IE5U6] Definition.

The final corpus of analysis for the Brazilian beach kiosk TWRs consists of 621 units of meaning, corresponding to 841 different category matches; the total corpus for the Australian beach kiosk TWRs consists of 640 units of meaning, corresponding to 930 different category matches.

\section{Discussion: two different tales on the edge}

\section{I Same categories, different frequencies}

TripAdvisor, as well as other standardized platforms of CORs, presents patterns. Cardon (2014), for example, identified eight categories of semantic groups ${ }^{20}$ in TripAdvisor hotel reviews. Vásquez (2010) and Cenni and Goethals (2017) also demonstrated patterns in TripAdvisor written negative evaluations. Further, Beuscart and Mellet (2016) analysed the "La Fourchette" application and showed patterns in what and how people write a review. Similarly, Gomes (2019) showed patterns of evaluation between

I8 The same unit of meaning B IE5U3 is allocated to two different categories: Location and Infrastructure. This is an example of how the same unit of meaning can be allocated to more than one category.

I9 In review B I E5, two different units of meaning ( $\mathbf{U} \mathbf{2}$ and $\mathbf{U} \mathbf{5}$ ) are allocated to the same category Food+Beverage. The same review can generate more than one unit of meaning to the same category.

20 The semantic groups are Definition; Narratives; Location; Service; Quality; Price; Recommendations; and Nuance (CARDON, 2014, p. 235). They are equivalent to what we are calling "categories" in our analysis. 
Airbnb users in Coimbra, Portugal and Porto Alegre, Brazil. These written patterns appear because, to write a review, one must fill a form with fixed metrics and evaluation criteria which guide what and how reviewers write $^{21}$. As a result, the same comparable categories emerge. However, in our case, although the same eight categories emerged from the analysis of both Brazilian and Australian beach kiosk TWRs, their frequencies vary, as shown in tables 1 and 2 .

Tables I and 2 - Frequency of units of meaning per category in analysis of TWRs of Brazilian and Australian beach kiosks
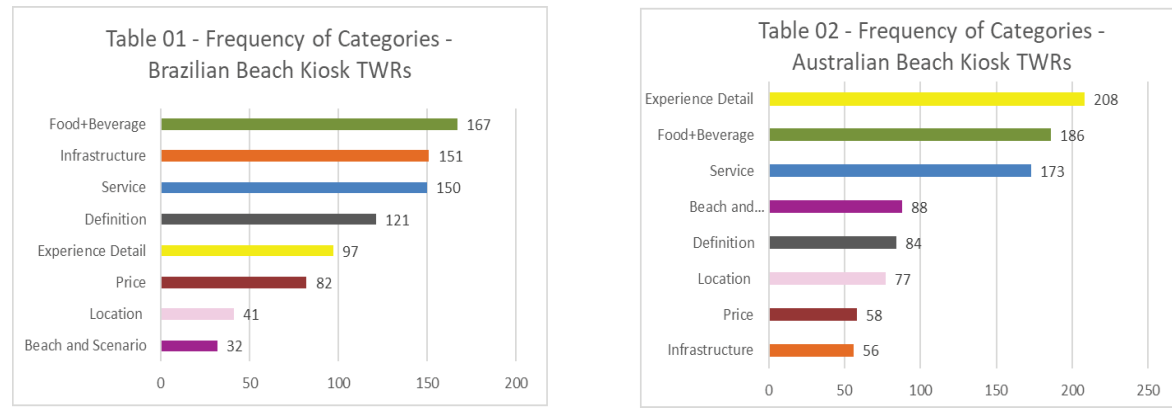

Source: Research Dataset - elaborated by the authors.

For the Brazilian beach kiosk TWRs, the categories that encompass most units of meaning are those related to the beach kiosk contractual experiences, such as Food+Beverage [167], Infrastructure [151] and Service [150]. They are followed by Definition [121] and Experience Detail [97], which bring subjective point of views about the kiosks. Although the beach kiosk experience implies commercial exchange, the category Price [82] comes only in sixth on the overall unit of meaning ranking. The lack of citations about the Location [41] and about the Beach and Scenario [32] shows a dissociation of consumer experiences with the natural landscape experience (SARTORE, 2017²2).

\footnotetext{
21 As TripAdvisor reviewers are amateurs, the platform provides a guide with tips on how to write a good review, aiming to create some sort of pattern. These guidelines are available at: https://www.tripadvisor.com/

22 The Brazilian beach kiosk TWRs dataset was previously analysed, in greater detail, in: Sartore, 2017.
} 
However, the frequency of categories in the Australian beach bar TWRs varied in comparison to the Brazilian beach kiosk TWRs. The categories that encompass most units of meaning in the Australian TWRs are Experience Detail [208], Food+Beverage [186] and Service [173]. The category with fewer allocated unit of meanings in the Brazilian TWRs analysis, Beach and Scenario, appears next in the Australian TWRs analysis, with 88 allocated units of meaning, showing a stronger association between the consumer experience with the beach setting for the kiosks. Definition [84] and Location [77] encompass less units of meaning, followed by Price [58]. Infrastructure, the second category in terms of allocated units of meaning in the Brazilian TWRs analysis, encompassed the least amount of units of meaning in the Australian TWR's analysis, with only 56 matches.

The sample of 400 TWRs was adequate in revealing the emergence of the same categories to express beachfront collective representation for both the Brazilian and the Australian case. However, the variability of their frequencies shows that there are different beachfront collective representations. These differences are highlighted by the content analysis of each category. With these general patterns in mind, we now focus more closely on three of them, in order to consider their relevance in showing similarities or idiosyncrasies between the Brazilian and Australian beach kiosk TWRs analysis. First, we drawn on Food+Beverage, as it was the category with most allocated unit of meanings in the Brazilian TWRs analysis and the second category with most allocated unit of meanings in the Australian TWRs analysis. Second, Beach and Scenario, as it was the category with least allocated units of meanings in the Brazilian TWRs analysis, appearing higher up in the ranking in the Australian TWRs analysis. Third, Infrastructure, as it was the category with least allocated units of meanings in the Australian TWRs analysis, and the second category with most allocated units of meanings in the Brazilian TWRs analysis.

What we aim to demonstrate with these three examples is that by analysing each category it is possible to better apprehend the variables that show the differences between the Brazilian and Australian beachfront collective representations. However, we acknowledge that other qualitative methods should be used in order to develop a deeper sociological analysis 
of beachfront collective representations ${ }^{23}$. Therefore, we conclude that TWRs are a good source to perceive differences in beachfront collective representations, but to explain their socio-logic, the analysis must go beyond the data sourced from TripAdvisor, and for this we draw on insights provided from document analysis and field observations.

\subsection{Different variables, different beachfront collective representations}

\subsection{Prawns, crab and beer, or eggs and coffee - looking at time}

Beach kiosks are places where people go to eat and drink. As a result, Food + Beverage is the category with the greatest number of allocated units of meaning in the Brazilian beach kiosk TWRs analysis [167 matches], and the second category in the Australian beach kiosk TWRs analysis [186 a total even greater than the category on the Brazilian side]. The content analysis of the Food+Beverage category showed that, among many different types of food, the most cited in the Brazilian reviews were "prawns" [21] and "crabs" [18]; as for the Australian reviews, the most cited were "eggs" [19], "lunch" [17] and "breakfast" [16]. As for the drinks, "beer" is the most cited in Brazilian reviews [28], and "coffee" in Australian reviews [44].
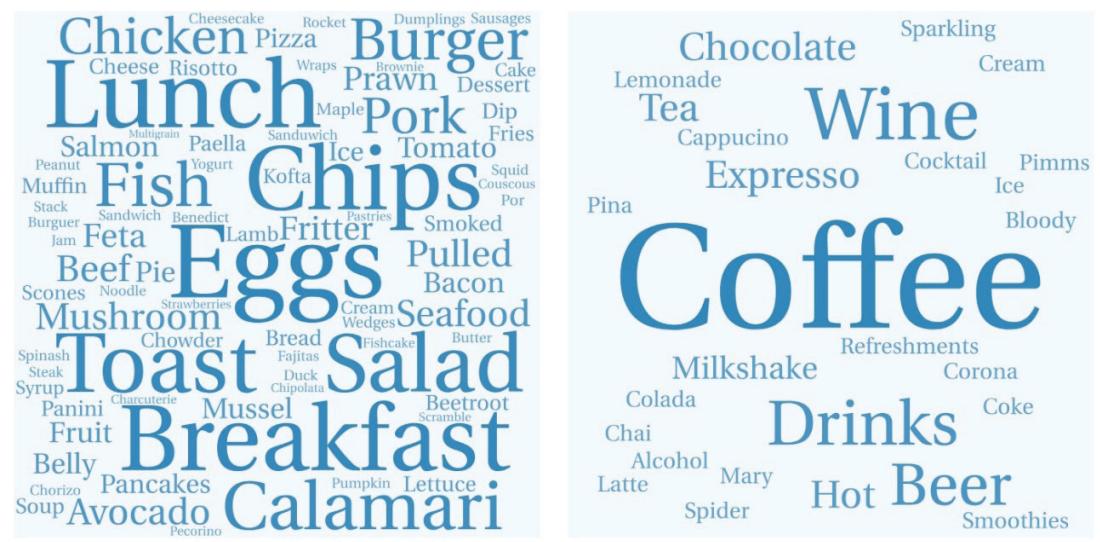

Figure I - Australian Beach Kiosks - Food+Beverage

Source: TWRs from our sample. Produced by the authors by using WordArt. In the word clouds, the font size gets bigger in direct proportion to the amount of times it is cited in the TWRs.

23 We cite them throughout the next section. 


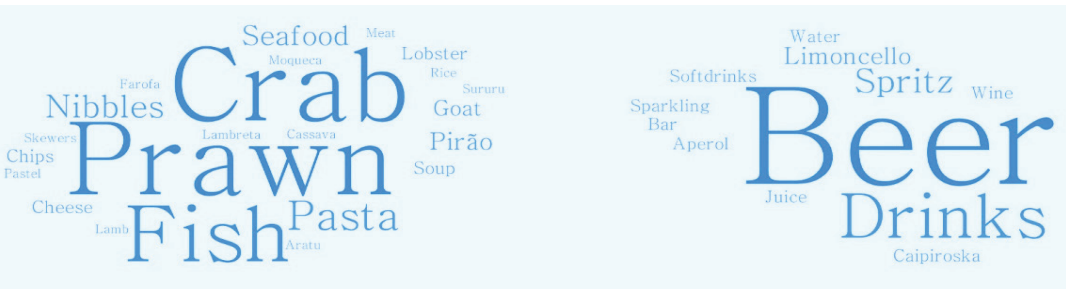

Figure 2 - Brazilian Beach Kiosks - Food+Beverage

Source: TWRs from our sample. Produced by the authors by using WordArt. In the word clouds, the font size gets bigger in direct proportion to the amount of times it is cited in the TWRs.

TWRs reproduce and reinforce the regional food identity. Although food identity can be stereotyped (WOOD; MUNOZ, 2007) ${ }^{24}$, it is an important aspect in building a national brand destination (LIN; PEARSON; CAI, 2011). However, the sociological understanding of the category Food+Beverage goes beyond listing and comparing different personal or general food tastes, such as "prawn, crab and beer" versus "eggs, lunch, breakfast, coffee". In fact, the main sociological assumption is that this pair of oppositions reveals different social relations in each case (BOURDIEU, 1984).

The first food beachfront collective representation analysed is "prawn, crab and beer". Aracaju is the fourth major prawn producer in Brazil (AGÊNCIA SERGIPE, 2014), but field observation revealed that the biggest star of beach kiosks in terms of menu is the crab, which has become an important source of income to the coastal communities of Sergipe (SANTA FÉ; ARAÚJO, 2013). Since 2016, the city has been organizing the Crab Festival (GURGEL, 2016) ${ }^{25}$, having also renewed the giant crab statue at the beach promenade $(\mathrm{G} 1,2016)^{26}$, a popular tourist attraction. As for drinks, field observation revealed umbrellas sponsored by beer brands. It is usual to see the waiter leaving a thermal bag full of beer bottles

24 The case explored by the authors is the international chain "Outback", seen as typical Australian food in the United States of America, but not recognized by Australians as such.

25 Information available at: http://hlog.turismo.gov.br/\%C3\%BAltimas-not\%C3\%ADcias/6559-festival-docaranguejo-agita-aracaju.html.

26 Information available at: http://gl.globo.com/se/sergipe/noticia/20/6/10/caranguejo-gigante-da-orla-daatalaia-passa-por-restauracao.html. 
near the leg of the table. After some time, the empty bottles are left on the opposite leg of the table so the waiter can count how many were consumed and print the bill. The thermal bag means that in the Brazilian beachfront collective representation, people spend a long time eating and drinking on the beach. Brazilian beach frontage drinking culture is reinforced by the summer beer advertisement campaigns (by different brands), often portraying the beach as a space for parties, with people having a good time while drinking beer on the beach (see references for "Nova Schin - Estação Cervejão" and "Comercial nova Schin" ${ }^{27}$ ).

The second food beachfront collective representation analysed is "eggs, lunch, breakfast, coffee". Field observation showed that in the Australian beach kiosks the experience is separated by time: in the morning, kiosks operate as beach cafes, where waiters and waitresses bring the breakfast menu and tables normally display coffee and eggs. However, sometime after noon, alcohol starts to be consumed at tables. By sunset, the metamorphosis is complete - the beach kiosks become bars, where most tables are adorned with alcoholic drinks ${ }^{28}$. During the morning, the busiest person is the barista; at sunset, the barman.

Taylor (2019) argues that urban spaces in Victoria are largely shaped by the alcohol drinking culture which still bears the legacy of the temperance era from the beginning of the $20^{\text {th }}$ century. Indeed, the division between coffee and beer drinking cultures and times seem to have a direct impact on the design of the Australian beach kiosk, as can be observed in figure three, which shows the space division in one of the beach kiosks with the cafe on the right side, the take-away food in the middle, and the bar on the left side.

27 Available at: https://www.youtube.com/watch?v=HNyI_4QvzOy; https://www.youtube.com/watch?v=gvmsMQkEEgu.

28 Although the Australian beach kiosks have the permit to sell alcohol from I lam onwards, it's very unusual to see people drinking alcohol before lunch time. 


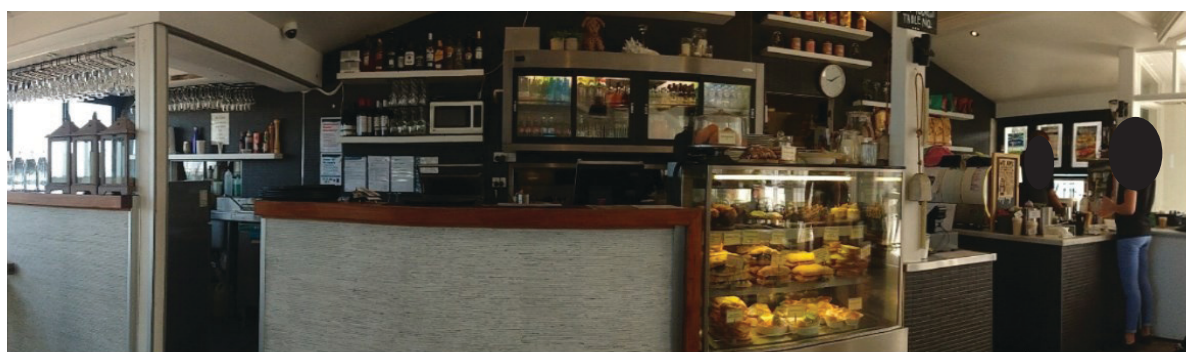

Figure 3 - Beach Kiosk in the morning (coffee to the right, bar to the left).

Source: Personal Photos. January/2019.

To test Taylor's argument, we undertook content analysis of eight Statutory Planning Documents about beach kiosk B ${ }^{29}$. The Statutory Planning Document states all of the normative framework (laws; agreed rules) related to the use of the land and presents the entire institutional history of the beach kiosk, including its controversies. Table 3 summarizes the history of beach kiosk B4.

Table 3 - Statutory Planning timeline for beach kiosk B4 ${ }^{30}$

\begin{tabular}{|c|c|}
\hline $\begin{array}{l}\text { Document } \\
\text { Date }\end{array}$ & Timeline \\
\hline $02 / 12 / 2002$ & $\begin{array}{l}\text { Local Council decides to advertise the call for potential developers of the old } \\
\text { bathing pavilion. }\end{array}$ \\
\hline $01 / 12 / 2003$ & $\begin{array}{l}3 \text { tenders were selected to "refurbish (...) in sympathy with the building's heritage, } \\
\text { to support community use and with limited, complimentary commercial uses } \\
\text { fronting the street and sea". (p. 85). }\end{array}$ \\
\hline 05/04/2004 & $\begin{array}{l}\text { The most recommended use for the building is as a food and beverage premise. } \\
\text { However, the building is on crown land and in Public Park and Recreational Zone } \\
\text { (PPRZ), where the use of the land for a restaurant is prohibited. }\end{array}$ \\
\hline
\end{tabular}

29 City of Port Phillip Statutory Planning Committee, 0 I December 2003, 05 April 2004, 26 April 2004, 13 June 2006, 23 March 2009, 0 I June 2009, 27 July 2009, 06 June 2018.

30 Statutory Planning of 200 I for B3 shows the same key issues raised by local community: Residential amenity, car parking, change of use of premises (local people wanted to avoid the place becoming a bar) and hours of operation. 


\begin{tabular}{|c|c|}
\hline $\begin{array}{l}\text { Document } \\
\text { Date }\end{array}$ & Timeline \\
\hline $26 / 04 / 2004$ & $\begin{array}{l}\text { The local council wants the insertion of the use for food and beverage facility } \\
\text { (excluding tavern and hotel) into the Public Park and Recreation Zone. Tavern } \\
\text { and hotel are excluded for having different liquor licences, allowing them to sell } \\
\text { alcohol without food. The restaurant should be a public facility, not a bar. }\end{array}$ \\
\hline 13/06/2006 & $\begin{array}{l}\text { A renovation plan includes a 300-seat restaurant/cafe, take-away services, } \\
\text { exhibition space, beach related retail and public amenities. The key issues raised } \\
\text { by the local community are car parking and hours of operation. The consultation } \\
\text { with residents resulted in the agreement that the establishment "should not be } \\
\text { granted general liquor licence as this would allow alcohol to be taken off the } \\
\text { premises and onto the beach and allow the serving of alcohol to persons on the } \\
\text { beach" (p. 123). }\end{array}$ \\
\hline $\begin{array}{l}23 / 03 / 2009 \\
01 / 06 / 2009\end{array}$ & $\begin{array}{l}\text { The partnership with a consortium is advertised to turn the building into a beach } \\
\text { facility as cafe and restaurant ( } 23 \text { March 2009). Key controversial issues are about } \\
\text { the amount to be paid by the tender as a lease. For local community, the decision } \\
\text { was favouring the tender rather than the local community interests ( } 0 \text { I June } \\
\text { 2009). }\end{array}$ \\
\hline 08/2009 & The cafe/restaurant is inaugurated with an on-premises liquor permit. \\
\hline 06/06/2018 & $\begin{array}{l}\text { After nine years, the kiosk applies for authorization to serve alcohol to the tables } \\
\text { on the beach, on the grounds that it is consistent with relevant current policy and } \\
\text { it is time for change. Local Council refused on the grounds that the role of the } \\
\text { kiosk is to bring public amenities and can't change it focus further towards alcohol } \\
\text { consumption. }\end{array}$ \\
\hline
\end{tabular}

Source: City of Port Phillip (200I, 2002, 2003, 2004a, 2004b, 2006, 2009, 2009b, 2009c, 2018). Table elaborated by the authors.

By looking at Table 3, it is possible to observe that the design of beach kiosk B4 is the result of protracted negotiations between the local council, law representatives, local community, and private sector interests. Discussions about drinking and the kiosk's status as a cafe, restaurant or bar were always on the agenda.

The TWRs gave us the first clues to the main differences between the Australian and the Brazilian beach kiosks in terms of Food+Beverage beachfront collective representation. A pair of oppositions appeared: "prawn, crab and beer" versus "eggs, lunch, breakfast, coffee". The combination of field observation and document analysis shows that two different beachfront collective representations derives from other different cultural backgrounds: in the Brazilian case, crabs and prawns are the 
result of a strong production associated with the city efforts to reinforce the crab as the city icon food identity. Also, there aren't any restrictions to having alcohol on the beach and beach kiosks are regularly supported by beer brands that encourage alcohol consumption on the beach ${ }^{31}$. As a result, Brazilian beach kiosks sell alcohol by the time they open and people normally spend the day on the beach drinking and eating. Quite differently, the Australian "eggs, lunch, breakfast, coffee" beachfront collective representation is determined by a cultural time division between breakfast and "after lunch" or happy hour, enforced by local morals and specific liquor permits that are negotiated in the governance processes described in the Statutory Planning Table. Looking back at the Brazilian scenario, the time division more clearly seen in Australian beachfront collective representations is blurred or non-existent.

\subsubsection{The view and the setting - looking at the space}

This section explores two major oppositions in the frequency of categories. The first opposition is that, while in the analysis of the Brazilian beach kiosk TWRs Beach and Scenario is the category with the least amount of allocated units of meaning [32], in the analysis of the Australian beach kiosk TWRs it is the category with the fourth most allocated units of meaning [88]. The second opposition is that, while Infrastructure is the second category regarding the total number of allocated units of meaning in the analysis of the Brazilian TWRs [151], it is the category with the least amount of allocated units of meaning in the analysis of the Australian TWRs [56]. This raises a few questions: Why does Beach and Scenario not appear as a relevant category regarding the Brazilian beachfront collective representation? And why is this different regarding the Australian beachfront collective representation? In a similar matter, why is Infrastructure not relevant for Australians? And why is so important for Brazilians?

The Beach and Scenario category refers to mentions to the beach and the surrounding scenario. In the Brazilian beach kiosk TWRs, Beach

3I In an informal conversation with one of the authors of this paper, one beach bar owner from Brazil measured his success as a beach kiosk entrepreneur by the amount of beer sold throughout the year. 
and Scenario usually refers to characteristics such as "quiet" [11] and "cleanliness" [7]. In the Australian beach kiosk TWRs, on the other hand, the "view" [60] and the "beach" [15] are predominant. Figure five shows a word cloud with the most cited words in the Beach and Scenario category for the Brazilian kiosks. Reinforcing the conclusions of a previous paper published by Sartore (2017), the lack of units of meaning associated to this category shows that the beach kiosk consumer experience is highly dissociated from experiences in nature ${ }^{32}$. In the Australian beach kiosk TWRs there are more mentions to the beach view as being something "great", "amazing", "lovely", "outstanding", "stunning", etc. (see all the words cited [including the most cited] in Australian TWRs in the word cloud presented as figure four).

Why do Australians put more stress on the beachfront view? Field observation in the Urban Expansion Zone in Aracaju showed around 50 beach kiosks ${ }^{33}$ scattered along 16 kilometres of the coast. On the other hand, field observation along 12 kilometres of the coast of Port Phillip Bay in Victoria showed two beach kiosks having direct access to the beach. The limited number of beach kiosks giving direct access to the beach in Port Phillip Bay explains, at least partly, why this beachfront experience is seen/ felt as unique ${ }^{34}$.

32 Sartore (2017) presents a complementary analysis of 138 pictures that were attached to the analysed TWRs showing that most of them (100) portrayed the kiosk's infrastructure, its food and beverages, while only 10 portrayed exclusively the beach or the surrounding nature.

33 Another field observation, including photographs, was undertaken in December 2017. The region was accessed by car. A group of students led by one researcher mapped 48 beach kiosks.

34 This uniqueness is commercially explored by the two Australian beach kiosks. B3's webpage slogan promises "Melbourne's most beachside cafe", while B4's slogan promises "A magnificent $E$ exclusive beach front venue". 


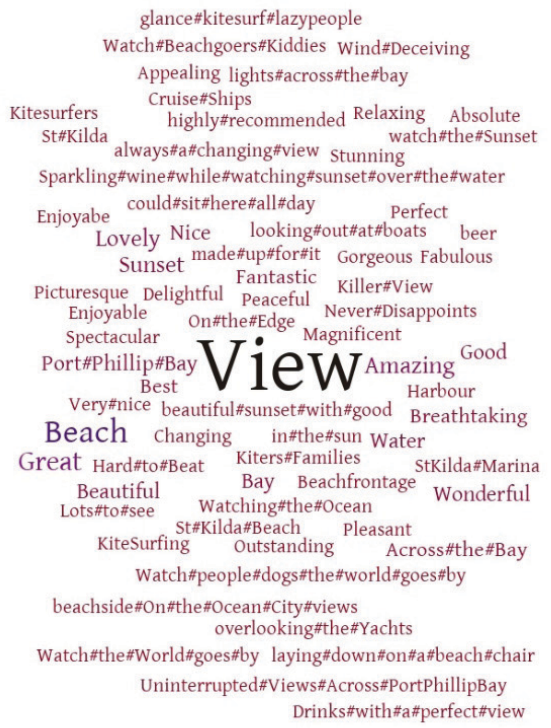

glance\#kitesurf\#lazypeople

Appealing lights\#across\#the\#bay

Cruise\#Ships

Fview Stunning

Sparkling\#wine\#while\#watching\#sunset\#over\#the\#water

Enjoyabe could\#sit\#here\#all\#day Perfect

ovely Nice looking\#out\#at\#boats bee

Sunset made\#up\#for\#it Gorgeous Fabulous

(never\#Disappoints

ort\#Phillip\#Bay $V \mathbf{1} e \mathrm{WAmazing}^{\text {Good }}$

Very\#nice beautiful\#sunset\#with\#good Breathtaking

in\#the\#sun Wate

Beautiful Bay Beachfrontage Wonderful

watching\#the\#Ocean

Surfing Outstanding Across\#the\#Bay

Watch\#people\#dogs\#the\#world\#goes\#by

\#Ocean\#City\#views

Drinks\#with\#a\#perfect\#view

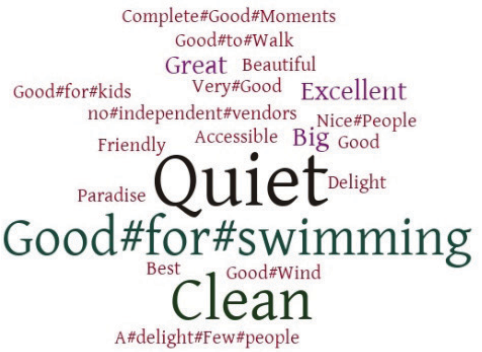

Good\#to\#Walk

Great Beautifu

ho\#independent\#vendors

Friendly Accessible Big Good

earatie Quiet

\section{Woredititut}

Woreditout

Figure 4 - "Beach and Scenario" word cloud. Australian beach kiosk TWRs on the left side, and Brazilian beach kiosk TWRs on the right side

Source: TWRs from our sample. Produced by the authors by using Worditout. In the word clouds, the font size gets bigger in direct proportion to the amount of times it is cited in the TWRs.

The Brazilian beach kiosks are literally built on the sand. The two Australian kiosks are built on the boardwalk, with their doors having direct access to the beach. Although there is a physical space division between the kiosk and the sand, for most reviewers of the Australian beach kiosks, they are "right on the beach" (see word cloud presented in figure five). The category Location [77] ${ }^{35}$ indicates that, as Australians don't have beach kiosks "on the sand", the sense of place is symbolically redefined, as they see the beach kiosks on the boardwalk as being "on the beach".

35 The category Location was brought to the analysis to complement the argument that, for reviewers of Australian beach bars, not only the view is unique, but also the location; even though the beach kiosks are physically built on the boardwalk, they are seen as being "on the beach". 


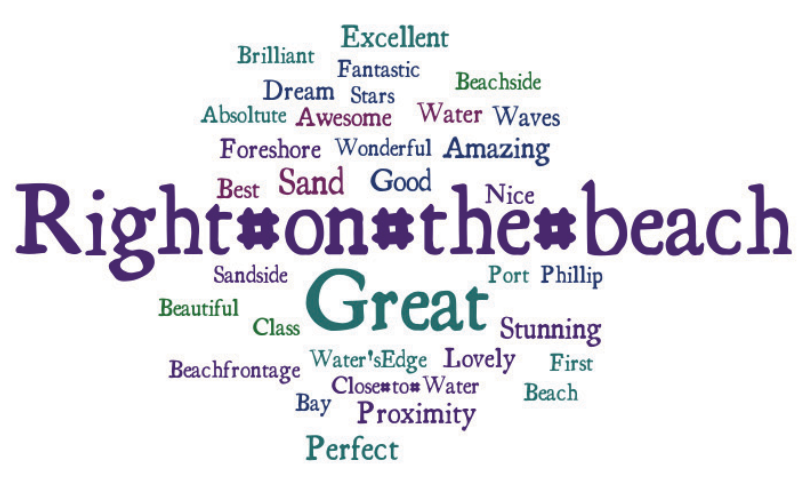

Wordititout

Figure 5 - "Location” word cloud, Australian beach kiosk TWRs

Source: TWRs from our sample. Produced by the authors using Worditout. In the word cloud, the font size gets bigger in direct proportion to the amount of times it is cited in the TWRs.

Infrastructure refers to facilities offered by beach kiosks, being the second category in number of matches for units of meaning in the analysis of Brazilian beach kiosk TWRs [151], but the least matches in the analysis of Australian beach kiosk TWRs [56]. In the Brazilian beach kiosk TWRs, the most cited words are "clean toilets" [22] and "furniture" [22], especially the quality of the chairs and tables. In the Australian TWRs, the most cited ones are "seating" (distribution) [30] - mostly the fact that there is indoor and outdoor seating [21], and "parking" [11].

Field observation showed that the beaches of Port Phillip Bay, including where the beach kiosks are, have changing rooms that are used by people to change clothes before and after enjoying the beach. The changing room implies a ritual that expresses the space division between the beach, where people use swimming suits, and the kiosk, where people get "properly dressed" for a meal. Differences in the way people dress (what "properly dressed" means) can also be observed in the kiosks: in the morning, people usually dressed casually, coming from or going to day activities and sports. At sunset, people typically dressed more formally. Sometimes an official note could be found near the entrance to the kiosk indicating the dress 
code. This clear space division between the beach and the kiosk leads to reviews that highlight indoor and outdoor seating arrangements, especially since beach kiosks B3 and B4 have very few tables on the sand, some on the deck and the majority indoor.

Very differently, Brazilian beach kiosks "merge" with the beach. They offer small toilets, but no changing rooms. There aren't public toilets available near them. Although "clean toilets" are the most cited words in the Brazilian beach kiosk TWRs, customers regularly stay dressed with beach clothes the whole time. Consequently, the second most cited words for the Brazilian beach kiosks are related to the comfort and quality of chairs and tables. Figure six show the difference in the design of tables and chairs. In the Brazilian kiosks, there are more tables outdoor (on the sand). In the Australian kiosk, the tables are predominantly placed indoors.

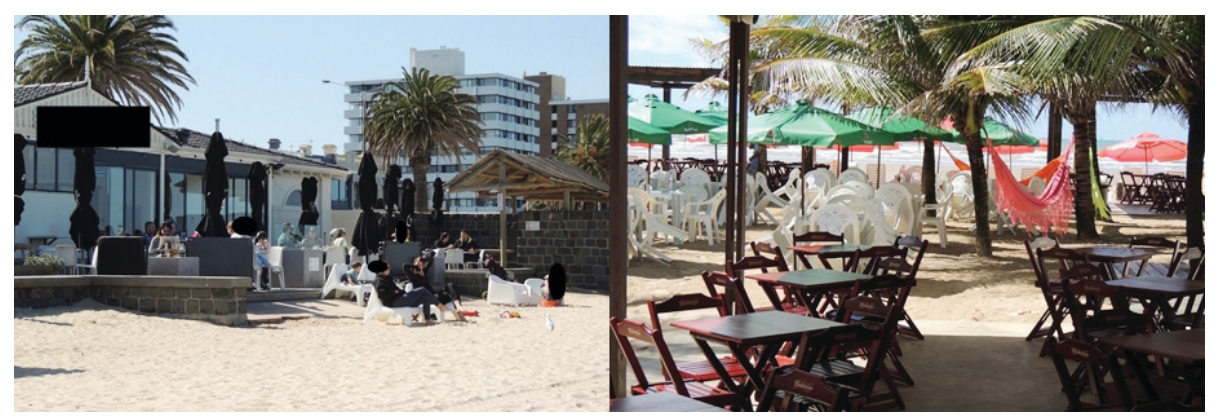

Figure 6 - Design of tables - Australian beach kiosk (on the left) and Brazilian beach kiosk (on the right).

Source: Personal Photos. On the left: January 2019. On the right: December 2017.

The content analysis of beach kiosks B3 and B4 Statutory Planning ${ }^{36}$ gives us some clues for the reason why Brazilian beach kiosk TWRs show greater concern with infrastructure than the Australian beach kiosk TWRs. In the Australian case, both B3 and B4 are heritage buildings built at the first half of the $20^{\text {th }}$ century as bathing facilities. The plans to revitalize

36 B3 Statutory Planning, City of Port Phillip Bay, December 02 ${ }^{\text {nd }}, 2001$. 
kiosks B3 and B4 started, respectively, in 1989 and in 200237. The process that led to the creation of these two beach kiosks operating as cafes and restaurants is the same: the tenders proposed a revitalization project that needed to follow the law - especially those concerning lease on crown land (VICTORIA STATE GOVERNMENT, 2018) ${ }^{38}$. Then, it had to get the approval from the local council, the local community and the authorities in the field of sustainability, heritage, land and urban development. Relevant issues, such as the size, colour and heritage frontage of the building, the extension of glass windows, the distribution of indoor and outdoor tables, the sewage system, the garbage disposal, were previously discussed in the project. After bringing the major controversies to an agreement, the kiosks were granted all the permits and were ready to operate, but they keep being monitored by local people and the local council.

The formalisation of local community participation in coastal management in Victoria started with the Coastal Management Act Victoria 1995 (WESCOTT, 1998), reaching a point where the local community interests can sometimes overcome expert recommendations, such as in a case in South Australia where the local community decided to rebuilt a Surf Life Saving Club, despite the environmental expert's recommendations against it (CLARKE; TUALLY; SCOTT, 2016). As both beach kiosks B3 and B4 went through the same institutional process, both have similar designs and the same basic infrastructure. Therefore, Victorian beach kiosk costumers are more likely to know what kind of infrastructure they'll find, which, in turn, can impact on the lack of mentions related to Infrastructure on TWRs.

As for the Brazilian case, interviews and a lawsuit content analysis can explain the greater mentions on Infrastructure in the TWRs. A set of interviews with 16 out of the 48 Brazilian beach kiosk owners ${ }^{39}$ revealed

37 This period coincides with the Kennett Government (1992-1999) in Victoria, when a business oriented approach was introduced to public sector management and decision-making (COFFEY, 200I).

38 Laws related to lease on crown land available at: https://www.forestsandreserves.vic.gov.au/land-management/ crown-land-leases-licences-and-permits.

39 Interviews were conducted and recorded from January to May 2017 and transcribed from July 2017 to February 2018. The research is registered at the Federal University of Sergipe under the codes PVD 395 I-2016 and PVD $5178-2017$. 
that the Brazilian beach kiosks were created as rustic shacks back in the eighties ${ }^{40}$. Since then, they have been renewed with brick structure, new amenities and have been expanding the number of tables and chairs. However, these beach kiosks are being sued by the Brazilian Public Ministry (lawsuit number 0802585-36-2014.4.05.850013) since 2014, on the grounds that (1) they irregularly occupy crown land, as they don't have either the environmental licence neither the licence to operate; (2) their uncontrollable growth is blocking the free access to the beach which is guaranteed by the Brazilian Federal Constitution of 1988 (SARTORE; ARAÚJO; RODRIGUES, 2019).

The interviews with beach bar owners revealed the predominance of a sense of institutional uncertainty. They say that some kiosks are better monitored than others, some have more privileges than others. The very existence of the lawsuit to demolish the Brazilian beach kiosks proves that this market grew unsystematically, with informal rules taking over, and now needs to be regulated. The lack of institutional certainty leads to unpredictable infrastructure, explaining the emphasis on this subject in the Brazilian beach kiosk TRWs.

\section{Conclusion}

This special issue on "Market, Media and Consumption" stresses important questions on how sociology can understand the changes in markets, especially in the wake of online applications that bring large scale datasets produced by algorithms. As we argued in this article, TWRs are useful to better understand the beachfront collective representations in Aracaju and Port Phillip Bay. The TWRs are mostly published by "experienced" local amateur contributors of TripAdvisor who are probably part of a high-income group.

The case studies are four local beach kiosks. The Brazilian beach kiosk TRWs are written mainly by Brazilians, and the Australian beach kiosk TRWs are written mainly by Australians. This means that the analysis

40 There is no similar document to an Australian Statutory Planning regarding the institutional history of these beach kiosks available to public consultation, justifying the need for interviews. 
can be a faithful picture of the beachfront collective representations in a national level ${ }^{41}$. The TWR analysis shows how Brazilian and Australian CORs evaluate the beachfront experiences in beach kiosks in a similar way, seeing the same eight categories emerge from the analysis. However, the significance of each category varies in the Brazilian and Australian reviews, as evidenced by the number of units of meaning allocated to each category. In analysing these variations we can understand how the beachfront collective representations are different in each of the two countries.

We also argued that to be able to explore the major differences and oppositions between the Brazilian and the Australian beachfront collective representations we need to combine the analysis of TWRs with other qualitative research methods, such as field observation and document analysis. We selected three noteworthy categories to demonstrate our argument: Food+Beverage, showing how both Brazilian and Australian TWRs regard beach kiosks mainly as places to eat and drink; Beach and $\underline{\text { Scenario, }}$ showing how the setting of the bar is much more important to Australian than to Brazilian CORs (probably because of the uniqueness of the beach kiosk experience in Australia); and Infrastructure, showing how this is a matter of greater concern to Brazilian than to Australian CORs (probably because of the lack of regulation in how beach kiosks are built in Brazil). By developing content analysis combined with field observation and document analysis (and other complementary methods, such as photography and video analysis and interviews, for the Brazilian case), it is possible to broaden the analysis to grasp the socio-logics driving the beachfront collective representations, which showed differences in Australia and Brazil in two main dimensions: time and space.

Food+Beverage showed the difference in the time dimension. The opposition between "prawn, crab and beer" and "eggs, lunch, breakfast and coffee" showed Aracaju's effort to associate the beachfront collective representation to prawns and crabs, which are important sources of income to the local community. Prawns and crabs are typically eaten accompanied by a cold beer. At the Australian side, people associate the beachfront

4I The comparative analysis can also be developed at other levels. For example, between Brazilians beach kiosks, or between Australian beach kiosks. Or even between two beach kiosks of the same city. 
collective representation with eggs and coffee, a popular breakfast meal. The "what people eat" revealed by the TWRs is important; however, it was the "how people eat" revealed by the field observation that showed the differences in the time dimension. The Australian beachfront collective representation is divided between "coffee and eggs" in the morning, and "lunch and drinks" in the afternoon. This time division doesn't exist in Brazilian kiosks. By further exploring the Australian case with document analysis, we could understand that the beachfront collective representation is highly associated with the Australian drinking collective representation, which still carries some of the conservative morals of the temperance movement from early $20^{\text {th }}$ century. This connection between beachfront and drinking collective representations seems to also be quite strong in Brazil, however, in a very different way, where beach kiosks are regularly supported by beer companies which promote the "whole day drinking on the beach" culture.

Beach and Scenario and Infrastructure highlight the differences in the space dimension. The lack of units of meaning for Beach and Scenario in the Brazilian TWRs shows the dissociation between the kiosk experience with the surrounding nature. As Brazilians have many beach kiosks on the sand, they take them for granted. In Australian TWRs, this category encompassed more units of meaning, where reviewers characterized beach kiosks with direct access to the sand (for Australians, "right on the sand") as rare and unique beachfront experiences.

The lack of units of meaning for Infrastructure in the Australian TWRs is most likely associated to the high predictability of beach kiosk infrastructure, seeing the owners must face a governance process to be able to open their commercial venues; hence, good infrastructure is taken for granted. Very differently, the high volume of units of meaning for infrastructure in the Brazilian TWRs, along with document analysis on the Brazilian Federal Public Ministry lawsuit against the beach bars, shows how the informality of how Brazilian beach kiosk are built leads to an unpredictable infrastructure, being clean toilets the major concern. Another difference revealed by the Infrastructure in the Brazilian beach kiosk TWRs is the quality of chairs and tables. Since people stay the whole 
day at the same place, the beach kiosk merges with the beach, providing mostly outdoor seating (on the sand). In the Australian beach kiosk TWRs, the seating distribution (outdoor or indoor) also matters, since there is a physical division between the kiosk and the beach (a result of the changing room culture, and the need to change clothes, as each space has different dressing codes). There are few tables outdoor (on the sand), some on the deck and many indoor. Therefore, the access to a "clean" beachfront is very disputed and, most of the times, the deck is the closest one can get to the beach.

TWRs are adequate datasets as a starting point or complement to field observations and document analysis. This article focused on the demand side, but to be able to accomplish the whole sociological task and understand this form of commerce on the beach, we also need to bring the supply side. Therefore, the cherry on the cake would be to bring the relevant social actors from beer companies, coffee companies, heritage associations, local community leaders, beach kiosk owners to understand how the supply side affects beachfront collective representations.

Beachfront collective representation is an important matter for sociologists, since it changes along with society. Understanding beachfront collective representations of different countries can bring consistent knowledge to help politicians tackle current coastal challenges, especially the balance between commercial development and natural conservation of the beachfront.

\section{References}

ABS. 8146.0 - Household Use of Information Technology, Australia, 2016-17. March $^{\text {th }} 2018$. Available at: https://www.abs.gov.au/ausstats/abs@.nsf/mf/8146.0. Accessed on: March 222019.

AGÊNCIA IBGE NOTÍCIAS. PNAD Contínua TIC 2016: 94,2\% das pessoas que utilizaram a internet o fizeram para trocar mensagens. 10 abr. 2018. Available at: https://agenciadenoticias. ibge.gov.br/agencia-sala-de-imprensa/2013-agencia-de-noticias/releases/20073-pnad-continua-tic2016-94-2-das-pessoas-que-utilizaram-a-internet-o-fizeram-para-trocar-mensagens. Accessed on: March $22^{\text {nd }} 2019$.

AGÊNCIA SERGIPE. Sergipe é o $4^{\circ}$ maior produtor de camarão do Brasil. Available at: http:// agencia.se.gov.br/noticias/meio-ambiente/sergipe-e-o-4-maior-produtor-de-camarao-do-brasil. Accessed on: March 26 2019. 
AMAZON. 2019. Available at: https://www.amazon.com. Accessed on: March $20^{\text {th }} 20190$.

AZEVEDO, T. A praia: espaço de sociabilidade. In: SOUZA, R. V. de; LAGE, V. (org.). A economia da praia. Brasília: SEBRAE, 2008. p. 201-218.

BEAUVISAGE, T.; BEUSCART, J.-S.; CARDON, V.; MELLET, K.; TRESPEUCH, M. Notes et avis des consommateurs sur le web - les marchés à l'épreuve de l'évaluation profane. Réseaux, n. 177, p. 131-61, 2013.

BOURDIEU, P. Distinction. A social critique of the judgement of taste. Massachusetts: President and Fellows of Harvard College and Routledge \& Kegan Paul Ltd, 1984.

BOYD, D.; CRAWFORD, K. Critical Questions for Big Data. Information, Communication \& Society, v. 15, n. 5, p. 662-679, 2012.

CARDON, V. Des chiffres et des lettres. Évaluation, expressions du jugement de qualité et hiérarchies sur le marché de l'hôtellerie. Réseaux, n. 183, p. 207-245, 2014.

CARDON, D. À quoi rêvent les Algoritmes - Nos vies à l'heure des big data. Paris: Seuil, 2015.

CENNI, I; GOETHALS, P. Negative hotel reviews on TripAdvisor: A cross-linguistic analysis. Discourse, Context \& Media, v. 16, p. 22-30, 2017.

CITY OF PORT PHILLIP. Statutory Planning Committee. 12 Feb. 2001.

CITY OF PORT PHILLIP. Strategy and Policy Review Committee. 2 Dec. 2002.

CITY OF PORT PHILLIP. Strategy and Policy Review Committee. 1 Dec. 2003.

CITY OF PORT PHILLIP. Strategy and Policy Review Committee. 5 April $2004 \mathrm{a}$.

CITY OF PORT PHILLIP. Supplementary Report. 26 April $2004 \mathrm{~b}$.

CITY OF PORT PHILLIP. Statutory Planning Committee. 13 June 2006.

CITY OF PORT PHILLIP. Ordinary Meeting Council. 23 March 2009a.

CITY OF PORT PHILLIP. Strategy and Policy Review Committee. 1 June 2009b.

CITY OF PORT PHILLIP. Ordinary Meeting Council. 27 July 2009c.

CITY OF PORT PHILLIP. Ordinary Meeting Council. 6 June 2018.

CLARKE, B; TUALLY, S; SCOTT, M. Social networks and decision-making for coastal landuse planning, development and adaptation response. Australian Journal of Maritime \& Ocean Affairs, v. 8, n. 2, p. 101-116, 2016.

COFFEY, B. National Park Management and the Commercialisation of Nature: The Victorian Experience. Australian Journal of Environmental Management, v. 8, p. 70-78, June 2001.

COMERCIAL Nova Schin - Caveirinhas com JR Requeijo. (30 seg.). Armyagencytv, 15 ago. 2012. Available at: https://www.youtube.com/watch?v=gvmsMQkEE9U. Accessed on: March $26^{\text {th }}$ 2019. 
CORBIN, A. Territoire du Vide. L'occident et le désir du rivage (1750-1840). Paris: Ed. Flammarions, 1990. [1st ed. 1988].

COUSIN, S.; CHAREYRON, G.; DA-RUGNA, J.; JACQUOT, S. Étudier TripAdvisor. Ou comment Trip-patouiller les cartes de nos vacances. EspacesTemps.net, 29 ago. 2014. Available at: http://www.espacestemps.net/articles/etudier-tripadvisor/. Accessed on: Feb. $12^{\text {th }} 2019$.

DURKHEIM, E. Répresentations individuelles et répresentations collectives. Revue de Métaphysique et de Morale, v. 6, p. 3-22, 1898.

DURKHEIM, E. Jugements de valeur et jugements de réalité. Révue de Métaphysique et de Morale, v. 19, p. 1-13, 1911.

GERRIE, A. Worlds 50's beachs bar. CNN, June 17 ${ }^{\text {th }}$ 2013. Available at: https:/edition.cnn.com/ travel/article/worlds-best-beach-bars/index.html. Accessed on: March 28 2019.

GOLD, M. K.; KLEIN, L. Debates in the Digital Humanities. Minneapolis: University of Minnesota Press, 2016.

GOMES, G. M. Algo dita o Ritmo! O Airbnb e as representaçóes coletivas: quando o vínculo social é marcado pelo desempenho. Advisor: Elaine da Silveira Leite. 2019. 125 f. Dissertation (Masters of Sociology) - Postgraduate Program of Sociology, Federal University of Pelotas, Pelotas, 2019.

GURGEL, G. Festival do Caranguejo agita Aracaju. 2 ago. 2016. Available at: http://hlog. turismo.gov.br/\%C3\%BAltimas-not\%C3\%ADcias/6559-festival-do-caranguejo-agita-aracaju. html. Accessed on: March 26 2019.

G1. Caranguejo gigante da Orla da Atalaia passa por restauraçáo. 24 out. 2016. Available at: http://g1.globo.com/se/sergipe/noticia/2016/10/caranguejo-gigante-da-orla-da-atalaia-passa-porrestauracao.html. Accessed on: March 26 2019.

IR. TRIPADVISOR. TripAdvisor is the world's largest travel site. 2019. Available at: http:// ir.tripadvisor.com/. Accessed on: March 20 2019.

JEACLE, I.; CARTER, C. In TripAdvisor we trust: rankings, calculative regimes and abstract systems. Acc. Organ. Soc, v. 36, p. 293-309, 2011.

KARPIK, L. Le guide rouge Michelin. Sociologie du travail, v. 42, p. 369-89, 2000.

KINSTLER, L. How TripAdvisor changed travel. The Guardian, August $17^{\text {th }} 2018$. Available at: https://www.theguardian.com/news/2018/aug/17/how-tripadvisor-changed-travel. Accessed on: March 26 2019.

KITCHIN, R. Big Data, new epistemologies and paradigm shifts. Big Data \& Society, v. 1, p. 1-12, 2014.

LIN, Y-C.; PEARSON, T. E.; CAI, L. A. Food as a form of destination identity: a tourism destination brand perspective. Tourism and Hospitality Research, v. 1, n. 1, p. 30-84, 2011. 
MORAES, R. Uma tempestade de luz: a compreensão possibilitada pela análise textual discursiva. Ciência e Educaçáo, v. 9, p. 191-211, 2003.

NOVA Schin - Estação Cervejão - Comercial de TV. 5 de fev. 2014. (1 min.). Comerciais de TV, 5 de fev. 2014. Available at: https://www.youtube.com/watch?v=HNy1_4QvzOY. Accessed on: March $26^{\text {th }} 2019$.

ORLIKOWSKI, W. J.; SCOTT, S. V. What happens when evaluation goes online? Exploring apparatuses of valuation in the travel sector. Organization Science, v. 25, n. 3, p. 868-891, 2014.

PEYVEL, E. Mui Ne (Vietnam): Western tourists and locals, two different perceptions. Géographie et cultures, v. 67, p. 79-92, 2008.

SANTA FÉ, U. M. G.; ARAÚJO, A. R. R. Seletividade e eficiência das artes de pesca utilizada na captura de Ucides Cordatus (Linnaeus, 1763), Sergipe, Brasil. Acta Fish. Aquat. Res, v. 1, n.1, p. 29-44, 2013.

SANTOS, B. F. Apesar da expansão, acesso à internet no Brasil ainda é baixo. Exame, 2016. Available at: https://exame.abril.com.br/brasil/apesar-de-expansao-acesso-a-internet-no-brasilainda-e-baixo/. Accessed on: March 22 2019.

SARTORE, M. S. A representação coletiva dos bares e restaurantes "pé-na-areia” produzida pelo dispositivo "TripAdvisor": o caso de Aracaju-Sergipe. Tomo, n. 30, p. 303-336, June/July 2017.

SARTORE, M. de S. Australian beach Bar Trip Advisor Excel. Research Gate, April. 2019. Available at: https://www.researchgate.net/publication/332304794_Australian_Beach_Bar_Trip_ Advisor_Excel. Accessed on: March $22^{\text {nd }} 2019$.

SARTORE, M. S.; ARAÚJO, S. P.; RODRIGUES, C. Aracaju Beach Bars as contested Market: conflicts and overlaps between market and nature. Ocean \& Coastal Management, v. 179, p. 1-9, 2019.

SPEARRITT, P. Freedom and Commerce on the Australian Beach. Sport, Culture and Society, v. 3, p. 24-39, 2003.

STATISTA. Number of listing on TripAdvisor worldwide from 2014 to 2018, by type (in thousands). 2018. Available at: https://www.statista.com/statistics/684895/tripadvisor-numberof-listings-by-type/. Accessed on: March 21 st 2019.

URBAIN, J.-D. [1994]. Sur la Plage. Paris: Payot et Rivages, 2002.

TAMAJÓN, G. L.; VALIENTE, C. G. Barcelona seen through the eyes of TripAdvisor: actors, typologies and components of destination image in social media platforms. Current Issues, v. 20, n. 1, p. 33-37, 2015.

TAYLOR, E. J. Dry Zones: Planning and hangovers of liquor licencing history. Melbourne: Palgrave Pivot, 2019.

THOMAS, J.; WILSON, C.; PARK, S. Australia's digital divide is not going away. The Conversation, 2018. Available at: https://theconversation.com/australias-digital-divide-is-notgoing-away-91834. Accessed on: March $22^{\text {nd }} 2019$. 
Markets on the edge: Beach kiosk TripAdvisor consumer online reviews as dataset to compare Australian and Brazilian beachfront collective representations | Marina Sartore, Brian Coffey

TRIPADVISOR. 2019a. Available at: https:// www.tripadvisor.com. Accessed on: March $20^{\text {th }}$ 2019.

TRIPADVISOR. TripCollective FAQs. 2019b. Available at: https:/www.tripadvisor.com/vpages/ tripcollective_faqs.html. Accessed on: March 22 2019.

VICTORIA STATE GOVERNMENT. Crown land leases licences and permits. Crown land tenures support a wide range off amenities and uses. 2018. Available at: https://www. forestsandreserves.vic.gov.au/land-management/crown-land-leases-licences-and-permits. Accessed on: March $27^{\text {th }} 2019$.

YELP. 2019. Available at: https:// www.yelp.com. Accessed on: March $20^{\text {th }} 2019$.

WESCOTT, G. Reforming coastal management to improve community participation and integration in Victoria, Australia. Coastal Management, v. 26, n. 1, p. 3-15, 1998.

WOOD, N. T.; MUNOZZ, C. L. "No rules, just right" or is it? The role of themed restaurants as cultural ambassadors. Tourism and Hospitality Research, v. 7, n. 3-4, p. 242-255, 2007.

ZOMATO. 2019. Available at: Available at: https://www.zomato.com. Accessed on: March $20^{\text {th }}$ 2019.

Recebido: 09/04/2019

Aceito: 08/11/2019 


\section{Mercados na fronteira: avaliações online de consumidores de quiosques de praia como fonte de dados para comparar as representações coletivas de praia no Brasil e na Austrália}

\section{Resumo}

Avaliações de consumidores online suscitam desafios analíticos para as ciências sociais pois são escritas por amadores, são publicadas rapidamente e estão disponíveis para todos que tenham acesso à internet. Neste artigo exploratório, comparamos as Avaliações Escritas do TripAdvisor (AET) de quiosques de praia no Brasil e na Austrália e argumentamos que as AET são uma fonte útil para percebermos as diferenças nas representações coletivas da beira da praia. Argumentamos também que a análise de conteúdo das AET pode ser limitada; portanto, utilizamos outros métodos qualitativos como a análise documental e a observação de campo. Concluímos que as representações coletivas da beira da praia diferem pelas categorias de tempo e espaço. A compreensão das diferentes representações coletivas da beira da praia produz conhecimento para auxiliar políticas públicas a enfrentarem desafios contemporâneos no litoral, como a busca pelo equilíbrio entre o desenvolvimento comercial e a conservação da natureza.

Palavras-chave: Sociologia econômica. Litoral. Mídia digital. Consumo. Big data. 